IRELAND

\section{Education Renaissance in Galway}

A SIGNIFICANT milestone in the 120 year history of University College, Galway-and indeed in the history of higher education in Ireland-has recently been passed. A project consisting of a two-storey science building to house departments of biochemistry, chemistry and physics linked with a four-storey library block was set in motion earlier this month when Dr M. $O$. Knuthail, the college president, signed a contract worth $£ 2$ million with John Sisk and Sons Limited, a local building firm.

A grant for the development of University College, Galway, was announced at the end of 1967 by the late Mr Donagh O'Malley, then Minister for Education, and it will provide eventually for a single campus of some 3,000 acres, accommodating 6,000 students. The overall cost is estimated to be $£ 10-£ 12$ million. The first stage of the project, the science building and library, should be completed in time for the 1973-74 session.

'The University of Galway project is at least tangible evidence that Ireland is emerging from a period of stagnation in higher education. A report published earlier this year by the Organization for Economic Cooperation and Development drew attention to the slow development of higher education, and in particular to the lack of science and technology studentsprojections indicated that there should be about 19,000 students enrolled in Ireland's universities in 1970-71, of whom only 20 per cent are expected to study science and technology. The OECD report repeatedly pointed out that educational planning authorities have given insufficient attention to higher education during the $1960 \mathrm{~s}$.

\section{METEOROLOGY \\ Next Year's Forecust}

RELIABLE weather forecasts for up to a week ahead are promised by the Meteorological Office as one of the benefits of the new computer it is installing next year. And, according to the report of the office for 1969 (HMS@, London, 13s), daily forecasts should include the amount and distribution of rainfall that is expected over Britain and western Europe. The computer is to be an IBM System 360/Model 195the largest available from IBM - and as well as putting advances in mathematical modelling techniques into forecasting practice, it will be used to continue research into the evolution of large scale weather systems.

One prerequisite for better and quicker forecasting is a fast telecommunications system to deal with data from stations in Britain and overseas and with the growing quantity of information from weather satellites. Here the Meteorological Office is also bringing in more computers: the first stage of the automation of its telecommunications centre, which should be completed later this year, will establish it as a principal link in the Washington-Moscow trunk circuit of the World Weather Watch, and during the next few years the whole of the British data-gathering network will be modernized. This updating will include the setting up of an automated radiosonde system at sixteen weather stations, and operational trials of a number of completely automated stations.
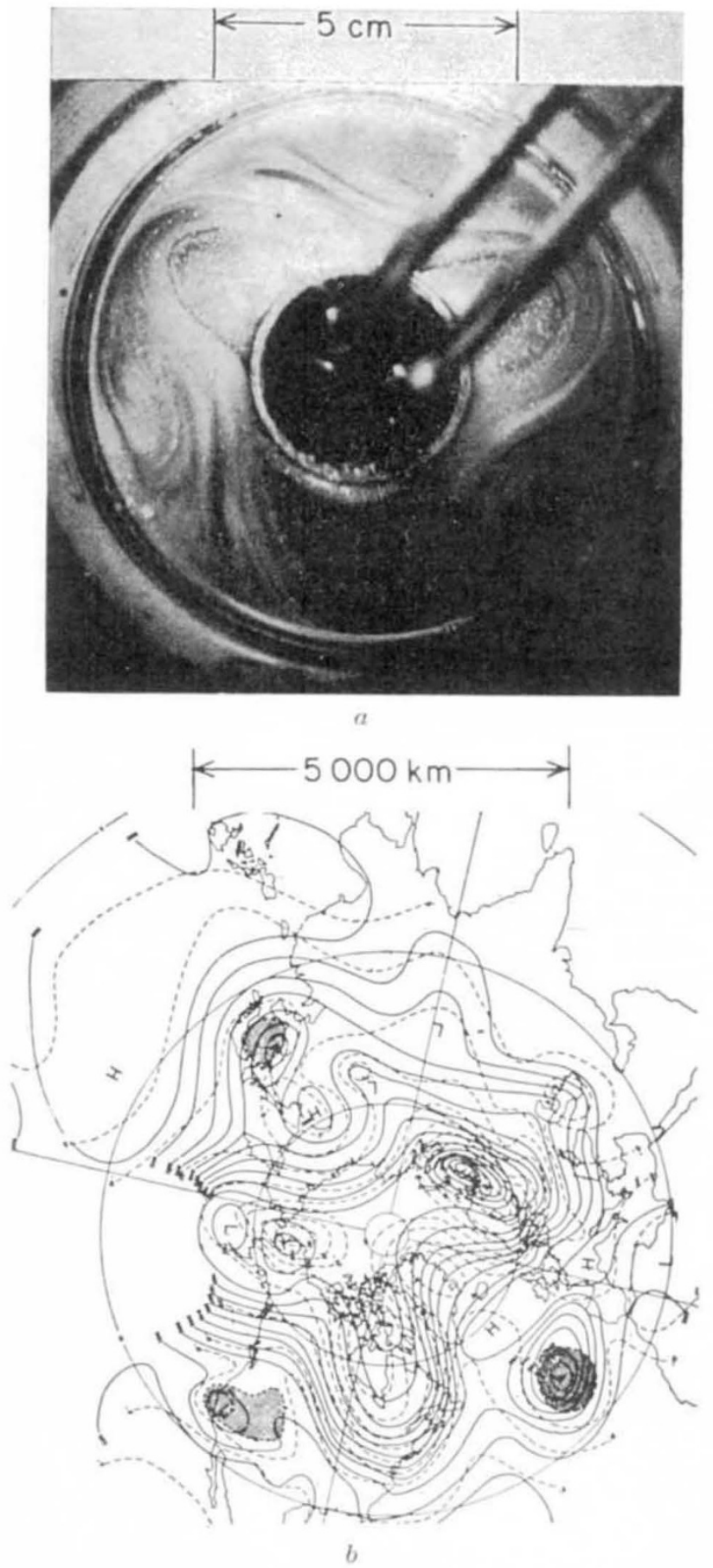

Simulating air movements in the laboratory. $a$ : the flow pattern at the top of a rotating annulus of water; $b$ : contours at intervals of 200 feet (-) and isotherms (-.) at the $500 \mathrm{mb}$ level for $0400 \mathrm{~h}$ on October 12, 1945. (Crown copyright.

Published by permission of the Controller of HMSO.)

On the research side, laboratory models of atmospheric motion have been helping, sometimes quite graphically, to show how complex movements on a large scale can be caused. The technique that a team under $\mathrm{Dr} \mathrm{R}$. Hide has developed uses rotating cylindrical pans of water, heated at the circumference and 